\title{
Effect of Spermine on the Kinetics of Estradiol Hydroxylation by Rat Liver Microsomes
}

It has been shown previously ${ }^{1}$ that liver microsomes derived from male rats convert a higher proportion of estradiol to its 2-hydroxy derivative and to water-soluble products than similar preparations from female rats. It is also known ${ }^{2}$ that the polyamines, spermine and spermidine produce a marked increase in the conversion of estradiol to water-soluble metabolites when added in vitro to rat liver microsomal preparations. It was therefore considered of interest to compare the kinetics of the reaction in these two systems to obtain more information about the factors which control the inactivation of estrogens by rat liver ${ }^{1}$.

[4-14 $\mathrm{C}]$ estradiol $(51.4 \mathrm{mC} / \mathrm{mmole})$ was obtained from Amersham-Searle, Toronto, and was shown by chromatography and autoradiography ${ }^{1}$ to be free of radioactive impurities. It was stored as a stock solution in ethanol $(1 \mathrm{mg} / \mathrm{ml}$ ). 60-90-day-old Holtzman rats, with free access to food and water were used. An $8000 \mathrm{~g}$ supernatant was prepared from the liver homogenate $(50 \mathrm{mg} / \mathrm{ml})$ as described previously ${ }^{1}$ and this fraction containing the microsomes was incubated at $37^{\circ} \mathrm{C}$ in $\mathrm{O}_{2}$ with $\left[4{ }^{14} \mathrm{C}\right]-$ estradiol, NADP $(0.3 \mathrm{mM})$ and glucose-6-phosphate $(3 \mathrm{mM})$ in $50 \mathrm{~m} M$ tris-HCl (pH 7.4) in the presence and absence of spermine $(0.25 \mathrm{mM})$. Incubations were usually carried out for $4,7,10$ and $15 \mathrm{~min}$ at $\left[{ }^{14} \mathrm{C}\right]$ estradiol concentrations of $0.625,1.25,2.5$ and $5 \mu \mathrm{g} / 3.5 \mathrm{ml}$.

The reaction was stopped by the addition of $1 \mathrm{M} \mathrm{HCl}$ $(1 \mathrm{ml})$ and the incubation mixture was extracted 3 times with equal volumes of peroxide-free ether. The radioactivity in each fraction was determined as before by liquid scintillation counting ${ }^{2}$. The velocity of the reaction in the double-reciprocal plots is expressed as nmoles of estradiol converted to water-soluble products per g wet wt. of tissue per min.

The results (Figure) are mean values from 11 experiments. They show that spermine added to microsomes from female rat liver alters the Michaelis constant $\left(K_{m}\right)$ for the oxidative metabolism of estradiol towards the values observed with male rat liver microsomes. The

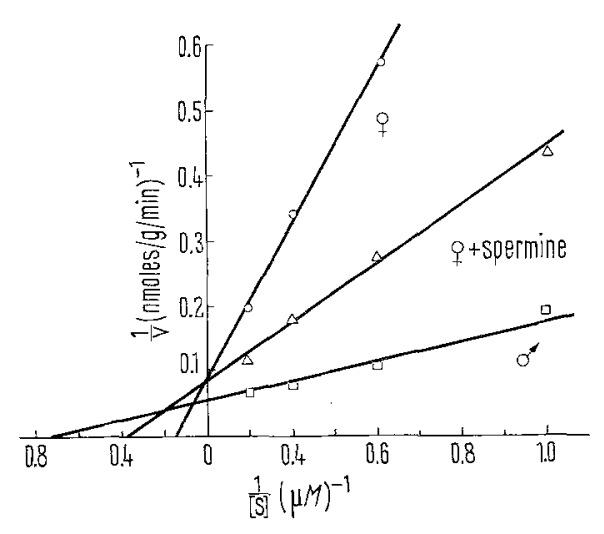

Double-reciprocal plots for the conversion of estradiol to watersoluble metabolites by rat liver microsomes. The velocity (v) is expressed as nmoles of estradiol converted to water-soluble products per $g$ wet wt. of tissue per min and the substrate concentration [S] as $\mu$ moles [4-14 C] estradiol $/ 3.5 \mathrm{ml}$ of incubation mixture. For male rats: $V_{m a x}=17.8 \mathrm{nmoles} / \mathrm{g} / \mathrm{min}, K_{m}=1.4 \mu M$; for female rats: $V_{\max }=12.5 \mathrm{nmoles} / \mathrm{g} / \mathrm{min}, K_{m}=7.1 \mu M$; for female rats + spermine $(0.25 \mathrm{~m} M): V_{\max }=12.5$ nmoles $/ \mathrm{g} / \mathrm{min}, K_{m}=2.6 \mu M$. maximum velocity $\left(V_{\max }\right.$ ) of the reaction was unaffected however, and the curves obtained for female rats in the double-reciprocal plots are typical of competitive inhibition and could be interpreted as the removal of an inhibitor by spermine.

The rate of formation of the biologically inactive watersoluble metabolites of estradiol has been shown to be proportional to the rate of formation of 2-hydroxyestradiol $^{2,3}$ and although it would have been desirable to use a more purified hydroxylating system, these oxidative enzymes have so far resisted solubilization and purification.

The effect of spermine cannot be explained by sexdifferences in the concentration of this polyamine which is present in approximately the same amounts in male and female rat liver ${ }^{4}$. It is more likely that spermine is acting by stabilizing the membranes of the endoplasmic reticulum containing the mixed-function oxidases involved in the reaction. This is supported by the observation that polyamines have little effect on the hydroxylation of estrogens by intact cells in which the microsomes are in a more natural and stable state ${ }^{2}$.

Polyamines are known to interact with RNA in the rough membranous endoplasmic reticulum ${ }^{5}$ and it is therefore possible that the in vitro activation of the estrogen hydroxylating system by spermine is brought about by removal of an inhibitor of this type. However, interaction of spermine with phospholipids or other negatively charged components of the membranes cannot be excluded and it is also possible that polyamines are activating the hydroxylating system either directly or by inhibiting lipid peroxidation in a linked system ${ }^{6}$.

A fuller understanding of the mechanism of action of spermine may therefore provide information about the factors which control the activity of enzymes associated with membranes ${ }^{7}$.

Résumé. L'addition de spermine au microsomes du foie de rats femelles modifie le $K_{m}$ du système enzymatique qui transforme l'estradiol en 2-hydroxyestradiol et aussi en des produits aqueux. La nouvelle valeur resemble à celle qu'ont trouve avec des rats mâles, mais le $V_{\max }$ de la réaction reste inchangé. L'action de la spermine dans ce système est discutée.

\section{P. H. JELIINCK and JANET COX}

Depariment of Biochemistry, Queen's University, Kingston (Ontario, Canada), 6 April 1970.

1 P. H. Jellinck and I. LUCieER, J. Endocr. 32, 91 (1965).

2 P. H. Jellinck and G. PerRy, Biochim. biophys. Acta 737, 367 (1967).

3 P. H. Jellinck and M. Garland, J. Endocr. 45, 75 (1969).

4 W. I. T. NeIsh, Biochem. Pharmac. 16, 163 (1967).

5 A. Raina and T. Telaranta, Biochim. biophys. Acta 738, 200 (1967).

6 E. D. Wrlls, Biochem. J. 113, 333 (1969).

7 This work was supported by the Medical Research Council of Canada. 